\title{
PREVALENCE OF PREHYPERTENSION AND HYPERTENSION AMONG MEDICAL GRADUATES IN MANIPUR AND ITS ASSOCIATION WITH RISK FACTORS
}

\author{
Yumnam Anjana Devi1, Keisam Reetu Devi², Avinash Keisam³
}

${ }_{1}^{1}$ Associate Professor, Department of Physiology, Jawaharlal Nehru Institute of Medical Sciences (JNIMS), Imphal, Manipur, India. ${ }^{2}$ Assistant Professor, Department of Physiology, Jawaharlal Nehru Institute of Medical Sciences (JNIMS), Imphal, Manipur, India. ${ }_{3}^{3}$ Assistant Professor, Department of Community Medicine, Jawaharlal Nehru Institute of Medical Sciences (JNIMS), Imphal, Manipur, India.

ABSTRACT
BACKGROUND
Hypertension is one of the common diseases associated with high morbidity and mortality. It is usually associated with various
modifiable risk factors like stress, high salt intake, high calorie intake, cigarette smoking, sedentary lifestyle etc. and non-
modifiable risk factors like genetic factor, gender and family history of cardiovascular disease. Early diagnosis and knowledge and
identification of predisposing risk factors are important for effective treatment and control of hypertension.
The study aims to assess the prevalence of prehypertension and hypertension among the medical students and find out the
association with its risk factors.

\section{MATERIALS AND METHODS}

This cross-sectional study was conducted in the undergraduate students studying in Jawaharlal Nehru Institute of Medical Sciences (JNIMS), Imphal. A pretested and prevalidated proforma was filled by the students after the purpose of the study was explained to them. This was followed by anthropometric measurements and blood pressure. The data was analysed using SPSS software version 22 by applying Chi-square test.

\section{RESULTS}

The study included 110 students, consisting of 64 males and 46 females. In our study, the prevalence of prehypertension was $8.2 \%$ and that of hypertension was $4.5 \%$. Among the males $12.5 \%$ were found to be pre-hypertensive, while $4.7 \%$ were found to be hypertensive. Among the female participants $2.3 \%$ were found to be pre-hypertensive, while $4.3 \%$ were found to be hypertensive. There was a significant association between BMI and prehypertension and hypertension. Since the calculated sample size was too high and thereby not feasible to include in this limited period of study, we had to limit the sample size for convenience.

\section{CONCLUSION}

The prevalence of prehypertension is more among the students as compared to prevalence of hypertension and more so in males as compared to females. The early intervention can help in reducing the development of hypertension. No significant association was found with prevalence and risk factors.

\section{KEY WORDS}

Prehypertension. Hypertension, Prevalence, Body Mass Index, Medical Students.

HOW TO CITE THIS ARTICLE: Devi YA, Devi KR, Keisam A. Prevalence of prehypertension and hypertension among medical graduates in Manipur and its association with risk factors. J. Evolution Med. Dent. Sci. 2018;7(28):3183-3187, DOI: $10.14260 /$ jemds/2018/716

\section{BACKGROUND}

The prevalence of Non-Communicable Disease (NCD) is increasing in both the developed and developing countries due to increased urbanisation, socio-economic development and changes in lifestyle of man. Cardiovascular Disease (CVD) is the leading NCD, which claimed 17.5 million lives in 2012 ( $46 \%$ of all NCD deaths). ${ }^{1}$ Hypertension is one of the common health problems associated with high morbidity and mortality. It is one of the important risk factors for development of

'Financial or Other Competing Interest': None.

Submission 20-06-2018, Peer Review 03-07-2018,

Acceptance 05-07-2018, Published 09-07-2018.

Corresponding Author:

Keisam Reetu Devi,

Assistant Professor

Department of Physiology,

Jawaharlal Nehru Institute of Medical Sciences (JNIMS),

Imphal-795005, Manipur, India.

E-mail: keisamreetu@yahoo.co.in anjana_y@rediffmail.com

DOI: $10.14260 /$ jemds $/ 2018 / 716$

\section{(c) (i) $(\Theta$}

cardiovascular diseases, stroke, nephropathy and retinal damage. ${ }^{2}$ Hypertension is directly responsible for $57 \%$ of all stroke deaths and $24 \%$ of all Coronary Heart Disease (CHD) deaths in India. ${ }^{3}$ Hypertension is usually associated with various modifiable risk factors like age, stress, high salt intake, high calorie intake, cigarette smoking, sedentary lifestyle, obesity and other non-modifiable risk factors like genetic factor and family history of CVD. Knowledge and identification of various risk factors is important for primordial prevention to reduce the incidence of hypertension in the community and prevention of complications due to hypertension. ${ }^{4,5}$ Prehypertension was introduced by Joint National Commission 7 (JNC7) on Prevention, Detection, Evaluation and Treatment of High Blood Pressure. Prehypertension has been defined as person having systolic blood pressure of 120 - 139 or diastolic blood pressure of 80 - 90.6 Studies have shown increased risk of progression to hypertension from pre-hypertensive stage than from normotensive stage. ${ }^{7}$ Identification of prehypertensive helps in increasing awareness and early intervention to make lifestyle and dietary modification to 
delay or even prevent progression to hypertension, thus reducing the burden of hypertension in the society.

The present study aims to find the prevalence of prehypertension and hypertension among the medical students who are from different socio-economic status, coming from both rural and urban areas of Manipur.

\section{MATERIALS AND METHODS}

This cross-sectional study was conducted on 200 students in which 110 students who satisfied the inclusion criteria was taken non-randomly by convenient sampling method who were studying in Jawaharlal Nehru Institute of Medical Sciences (JNIMS), Imphal, Manipur. The study population comprised of 64 males in age group of $19.61 \pm 1.30$ years and 46 females in age group of $19.73 \pm 1.06$ years. A pretested and prevalidated proforma was used to collect the various data including age, sex, family history of hypertension/diabetes, socio-economic status, sleep pattern, salt and calorie intake, smoking habits, alcohol consumption, physical activity, stress etc. Students were asked to fill up the proforma after the purpose of the study was explained to them and an informed written consent was obtained. The study was approved by the Ethical Committee of the college. This was followed by anthropometric measurements (height, weight, BMI) and blood pressure was recorded per WHO guidelines. Since the calculated sample size was too high and thereby not feasible to include in this limited period of study, we had to limit the sample size for convenience. Weight was measured by using a standard weighing machine without shoes to the nearest $0.5 \mathrm{~kg}$ and height was measured by using a height meter without shoes to the nearest $0.5 \mathrm{~cm}$. Body Mass Index (BMI) was calculated using Quetelet index and WHO classification ${ }^{8}$ was used for interpretation of findings.

\section{Subjects were classified according to their Body Mass Index (BMI) as: \\ 1. Underweight: $<18.5 \mathrm{~kg} / \mathrm{m}^{2}$ \\ 2. Normal Weight: $18.5-24.9 \mathrm{~kg} / \mathrm{m}^{2}$ \\ 3. Overweight: $25-29.9 \mathrm{~kg} / \mathrm{m}^{2}$ \\ 4. Obese: $\geq 30 \mathrm{~kg} / \mathrm{m}^{2}$}

BP was recorded as per WHO guidelines. The criteria as per JNC 7 was followed for assessment of blood pressure. 6 The sitting position was used for recording the blood pressure, which was measured by using a mercury sphygmomanometer. The systolic and diastolic pressure was measured 3 times and an average reading was recorded. As per JNC 7 guidelines, subjects were classified as-

\section{Normotensive}

(Systolic blood pressure (SBP) $<120 \mathrm{mmHg}$ and diastolic blood pressure (DBP) $<80$.

\section{Pre-Hypertensive}

SBP- 120 - 139 mmHg or DBP 80 - 89.

\section{Hypertensive}

SBP $>140$ or DBP $>90$.

\section{Statistical Analysis}

- Data was analysed using SPSS version 22 by applying Chi-square test.

- $\quad \mathrm{P}<0.05$ was considered statistically significant.

\section{RESULTS}

The study included 110 students, consisting of 64 males in age group $19.60 \pm 1.30$ years and 46 females in age group $19.74 \pm 1.06$ years. As shown in Table 1 out of the total study population $96(87.3 \%)$ were normotensive, 9 (8.2\%) were pre-hypertensive and $5(4.5 \%)$ were hypertensive. Among the males $8(12.5 \%)$ were found to be pre-hypertensive, while $3(4.7 \%)$ were found to be hypertensive. Among the female participants $1(2.3 \%)$ was found to be prehypertensive, while $2(4.3 \%)$ were found to be hypertensive. In our study, the prevalence of prehypertension and hypertension was more in male students. A significant association was found between BMI and prevalence of prehypertension and hypertension, $(\mathrm{p}=0.008)$ (Table 2). As shown in Table 2 in the present study 1 (1.04\%) of normotensives was overweight, while $4(4.16 \%)$ were obese (BMI $\left.\geq 30 \mathrm{~kg} / \mathrm{m}^{2}\right) ; 1$ (11.1\%) of pre-hypertensive was overweight (BMI: $25.0-29.9 \mathrm{~kg} / \mathrm{m}^{2}$ ) and $8(88.9 \%)$ were with BMI between $18.5-24.9 \mathrm{~kg} / \mathrm{m}^{2}$ (Normal category). Among the hypertensive, 1 (20\%) of hypertensive was with BMI in normal range and $1((20 \%)$ was overweight and 1 (20\%) was obese. Prevalence of overweight among the participants were $2.7 \%$ and obesity was $4.5 \%$.

Table 3 shows the prevalence of various risk factors in the study population. Association between various risk factors was insignificant, but significant association with irregular sleep pattern with daytime somnolence $(p=0.034)$ was observed. Table 4 shows the presence of risk factors expressed as percentage. Most of the students are having a sedentary lifestyle with high intake of junk foods, all contributing to increase in blood pressure.

\begin{tabular}{|c|c|c|c|c|}
\hline $\begin{array}{c}\text { Category of } \\
\text { Hypertension }\end{array}$ & Male (n=64) & $\begin{array}{c}\text { Female } \\
(\mathbf{n = 4 6 )}\end{array}$ & $\begin{array}{c}\text { Total } \\
(\mathbf{n = 1 1 0 )}\end{array}$ & P value \\
\hline Normal & $53(82.8 \%)$ & $43(93.5 \%)$ & $96(87.3 \%)$ & \multirow{2}{*}{0.160} \\
\hline $\begin{array}{c}\text { Pre } \\
\text { hypertension }\end{array}$ & $8(12.5 \%)$ & $1(2.3 \%)$ & $9(8.2 \%)$ & \multirow{2}{*}{$0.5 \%)$} \\
\cline { 1 - 4 } Hypertension & $3(4.7 \%)$ & $2(4.3 \%)$ & $5(4.5 \%)$ & \\
\cline { 1 - 3 } & & &
\end{tabular}

Table 1. Distribution of Blood Pressure among the Subjects

\begin{tabular}{|c|c|c|c|c|c|}
\hline$\sum_{m}$ & 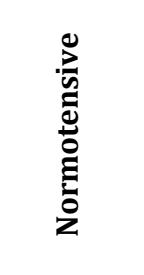 & 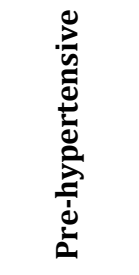 & 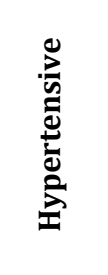 & 䒿 & $\begin{array}{l}\stackrel{0}{\Xi} \\
\stackrel{0}{\pi} \\
\text { D }\end{array}$ \\
\hline $\begin{array}{l}\text { Under- } \\
\text { weight }\end{array}$ & $\begin{array}{c}25 \\
(26.04 \%)\end{array}$ & $\begin{array}{c}0 \\
(0 \%)\end{array}$ & $\begin{array}{c}2 \\
(40 \%)\end{array}$ & $\begin{array}{c}27 \\
(24.5 \%)\end{array}$ & \multirow{4}{*}{0.008} \\
\hline Normal & $\begin{array}{c}66 \\
(68.8 \%) \\
\end{array}$ & $\begin{array}{c}8 \\
(88.9 \%)\end{array}$ & $\begin{array}{c}1 \\
(20 \%) \\
\end{array}$ & $\begin{array}{c}75 \\
(68.3 \%)\end{array}$ & \\
\hline $\begin{array}{l}\text { Over- } \\
\text { weight }\end{array}$ & $\begin{array}{c}1 \\
(1.04 \%)\end{array}$ & $\begin{array}{c}1 \\
(11.1 \%)\end{array}$ & $\begin{array}{c}1 \\
(20 \%)\end{array}$ & $\begin{array}{c}3 \\
(2.7 \%)\end{array}$ & \\
\hline Obese & $\begin{array}{c}4 \\
(4.16 \%)\end{array}$ & $\begin{array}{c}0 \\
(0 \%)\end{array}$ & $\begin{array}{c}1 \\
(20 \%)\end{array}$ & $\begin{array}{c}5 \\
(4.5 \%)\end{array}$ & \\
\hline
\end{tabular}




\begin{tabular}{|c|c|c|c|c|c|}
\hline 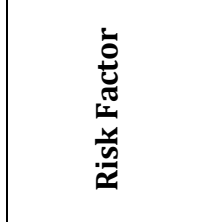 & & 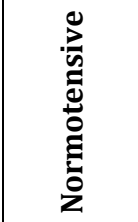 & d & 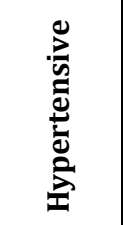 & $\begin{array}{l}0 \\
\frac{\pi}{2} \\
2\end{array}$ \\
\hline \multirow{2}{*}{$\begin{array}{c}\text { Irregular sleep } \\
\text { pattern with } \\
\text { daytime } \\
\text { somnolence }\end{array}$} & Yes & $\begin{array}{c}30 \\
(90.9 \%)\end{array}$ & $\begin{array}{c}0 \\
(0.0 \%) \\
\end{array}$ & $\begin{array}{c}3 \\
(9.1 \%)\end{array}$ & \multirow{2}{*}{$0.034^{*}$} \\
\hline & No & $\begin{array}{c}66 \\
(85.7 \%)\end{array}$ & $\begin{array}{c}9 \\
(11.7 \%)\end{array}$ & $\begin{array}{c}2 \\
(2.6 \%)\end{array}$ & \\
\hline \multirow{2}{*}{$\begin{array}{c}\text { Stress } \\
\text { present }\end{array}$} & Yes & $\begin{array}{c}15 \\
(88.2 \%)\end{array}$ & $\begin{array}{c}2 \\
(11.8 \%)\end{array}$ & $\begin{array}{c}0 \\
(0.0 \%)\end{array}$ & \multirow{2}{*}{0.692} \\
\hline & No & $\begin{array}{c}81 \\
(87.1 \% \\
\end{array}$ & $\begin{array}{c}7 \\
(7.5 \%) \\
\end{array}$ & $\begin{array}{c}5 \\
(5.4 \%) \\
\end{array}$ & \\
\hline \multirow{3}{*}{ Salt intake } & Often & $\begin{array}{c}22 \\
(84.6 \%)\end{array}$ & $\begin{array}{c}3 \\
(11.5 \%)\end{array}$ & $\begin{array}{c}1 \\
(3.8 \%)\end{array}$ & \multirow{3}{*}{0.756} \\
\hline & Occasional & $\begin{array}{c}37 \\
(92.5 \%)\end{array}$ & $\begin{array}{c}2 \\
(5 \%)\end{array}$ & $\begin{array}{c}1 \\
(2.5 \%)\end{array}$ & \\
\hline & Rarely & \begin{tabular}{|c|}
37 \\
$(84.1 \%)$
\end{tabular} & $\begin{array}{c}4 \\
(9.1 \%)\end{array}$ & $\begin{array}{c}3 \\
(6.8 \%)\end{array}$ & \\
\hline \multirow{2}{*}{ Diet } & $\begin{array}{c}\text { Non- } \\
\text { Vegetarian } \\
\end{array}$ & $\begin{array}{c}85 \\
(85.9 \%) \\
\end{array}$ & $\begin{array}{c}9 \\
(9.1 \%) \\
\end{array}$ & $\begin{array}{c}5 \\
(5.1 \%) \\
\end{array}$ & \multirow{2}{*}{0.760} \\
\hline & Vegetarian & $\begin{array}{c}11 \\
(100 \%)\end{array}$ & $\begin{array}{c}0 \\
(0.0 \%)\end{array}$ & $\begin{array}{c}0 \\
(0.0 \%)\end{array}$ & \\
\hline \multirow{3}{*}{$\begin{array}{l}\text { Intake of high } \\
\text { calorie } \\
\text { diet/fast food }\end{array}$} & Rarely & $\begin{array}{c}28 \\
(90.3 \%) \\
\end{array}$ & $\begin{array}{c}2 \\
(6.5 \%) \\
\end{array}$ & $\begin{array}{c}1 \\
(3.2 \%) \\
\end{array}$ & \multirow{3}{*}{0.983} \\
\hline & Occasional & \begin{tabular}{|c|}
51 \\
$(85.0 \%)$ \\
\end{tabular} & $\begin{array}{c}6 \\
(10.0 \%) \\
\end{array}$ & $\begin{array}{c}3 \\
(5.0 \%) \\
\end{array}$ & \\
\hline & Often & $\begin{array}{c}17 \\
(89.5 \%)\end{array}$ & $\begin{array}{c}1 \\
(5.3 \%)\end{array}$ & $\begin{array}{c}1 \\
(5.3 \%)\end{array}$ & \\
\hline \multirow{2}{*}{$\begin{array}{l}\text { Rarely do } \\
\text { exercise }\end{array}$} & Yes & $\begin{array}{c}66 \\
(84.6 \%)\end{array}$ & $\begin{array}{c}7 \\
(9.0 \%)\end{array}$ & $\begin{array}{c}5 \\
(6.4 \%)\end{array}$ & \multirow{2}{*}{0.602} \\
\hline & No & $\begin{array}{c}24 \\
(92.3 \%)\end{array}$ & $\begin{array}{c}2 \\
(7.7 \%)\end{array}$ & $\begin{array}{c}0 \\
(0.0 \%)\end{array}$ & \\
\hline \multirow{2}{*}{$\begin{array}{c}\mathrm{F} / \mathrm{H} \text { of } \\
\text { Cardiovascular } \\
\text { Disease (CVD) }\end{array}$} & Yes & $\begin{array}{c}17 \\
(89.5 \%)\end{array}$ & $\begin{array}{c}1 \\
(5.3 \%)\end{array}$ & $\begin{array}{c}1 \\
(5.3 \%)\end{array}$ & \multirow{2}{*}{0.837} \\
\hline & No & $\begin{array}{c}78 \\
(88.6 \%)\end{array}$ & $\begin{array}{c}7 \\
(8 \%)\end{array}$ & $\begin{array}{c}3 \\
(3.4 \%)\end{array}$ & \\
\hline \multirow[t]{2}{*}{$\mathrm{F} / \mathrm{H}$ of $\mathrm{DM}$} & Yes & $\begin{array}{c}16 \\
(88.9 \%)\end{array}$ & $\begin{array}{c}2 \\
(11.1 \%)\end{array}$ & $\begin{array}{c}0 \\
(0.0 \%)\end{array}$ & \multirow[t]{2}{*}{0.708} \\
\hline & No & $80(87 \%)$ & $7(7.6 \%)$ & $5(5.4 \%)$ & \\
\hline
\end{tabular}

$* \mathrm{P}<0.05$.

\begin{tabular}{|c|c|c|}
\hline Risk Factor Present & Total (n=110) & (\%) \\
\hline $\begin{array}{c}\text { Irregular sleep pattern with daytime } \\
\text { somnolence }\end{array}$ & 33 & 30 \\
\hline Stress present & 17 & 15.45 \\
\hline Salt intake & 26 & 23.64 \\
\hline Non-vegetarian diet & 99 & 90 \\
\hline Intake of high calorie diet/ fast food & 19 & 17.27 \\
\hline Rarely do exercise & 78 & 70.91 \\
\hline F/H of Cardiovascular Disease (CVD) & 19 & 16.36 \\
\hline F/H of DM & 18 & 17.27 \\
\hline
\end{tabular}

Table 4. Prevalence of Risk Factor (\%) among the Subjects

\section{DISCUSSION}

In our study, the total prevalence of Prehypertension was $8.2 \%$ and Hypertension was $4.5 \%$. Among the males $12.5 \%$ were pre-hypertensive, while $4.7 \%$ were hypertensive. Among the females $2.3 \%$ were pre-hypertensive, while $4.3 \%$ were hypertensive. The prevalence of prehypertension was low in our study population as compared to other studies in different parts of India, where they found prevalence ranging from $20 \%$ to $80 \% \cdot{ }^{9-14}$ In a study by Kumar Avadesh et al
(2014), the prevalence of hypertension was found to be $21.4 \%$ in males and $7.7 \%$ in females among medical students. ${ }^{5}$ Chitrapu et al (2016) observed prevalence of prehypertension in the study sample around $37.45 \%$, while $3.63 \%$ were hypertensive. 15 Studies in Manipur in various rural and urban areas have found lower prevalence as compared to other studies done in India. In a cross-sectional study of school going children in age group 5 - 15 years of age, the prevalence of prehypertension and hypertension were $17.5 \%$ and $15.3 \%$ respectively. ${ }^{16}$ Sathish Kumar et al, in their study found the prevalence of hypertension among age group of $\geq 25$ years in 2 urban communities of Imphal to be $37 \% .{ }^{17}$ Studies in rural area of Manipur found prevalence of hypertension and prehypertension to be $25 \%$ and $14.3 \%$ respectively.18 Studies have shown prevalence of hypertension among different Muslim populations of Manipur to be $18.16 \% .{ }^{19}$ Among the north-eastern states of India Manipur has different climatic condition, different dietary habits and cultural practices. These factors may be responsible for the relatively lower prevalence as compared with rest of India. In our study, the prevalence of hypertension is $4.5 \%$. Studies among medical students have found relatively lesser prevalence of hypertension among the students. Srivastava AK et al reported a prevalence of $10.5 \%$ in their study. ${ }^{20}$ Chhabra $\mathrm{P}$ et al reported lesser than $10 \%$ prevalence of hypertension. ${ }^{21}$ Chitrapu RV et al found 3.63\% of the study population were hypertensive. ${ }^{15}$ Kumar Avadhesh did not find any hypertension among the study group. ${ }^{5}$ Studies conducted in different parts and communities and tribes of India reported higher prevalence of hypertension. Vimala A et al reported 47\%,2 Tripathy JP et $\mathrm{al}^{22}$ found $40.1 \%$ prevalence, study by Sathya Prakash Manimunda et $\mathrm{al}^{23}$ found prevalence of $50.5 \%$ of hypertension among the aboriginal Nicobarese tribe. Studies in different urban and rural population of Manipur reported higher prevalence than the present study, Sathish Kumar et al $^{17}$ (37\%), Himadri Bhattacharya et al ${ }^{18}$ (25\%) and Ahsana Shah et $\mathrm{al}^{19}(18.16 \%)$.

This lower prevalence among the students may be due to higher awareness and higher education level among the students. Changing dietary habits and sedentary lifestyle with stressful environment may contribute to rise in blood pressure among the students. In our study, a significant association between BMI and prehypertension and hypertension ( $p=0.008$ ) was found, while association between other variables was not significant. Similar to our study, studies have observed that elevated BMI contributes to high blood pressure in their study population. ${ }^{24}$ Kulkarni MM et $\mathrm{al}^{13}$ and Setty SS et al ${ }^{11}$ in their study found positive correlation between prehypertension and BMI. Contrary to our findings, studies have observed that there was no association between elevated BMI and hypertension.25,26 Though significant association was not found in our study with various risk factors. Other studies have shown high prevalence of cardiovascular risk factors among medical students. ${ }^{27-29}$ In our study, significant association $(p=0.034)$ was found between irregular sleep pattern and prehypertensive and hypertensive state. Similar to our study, studies have found significant association of disturbed sleep with hypertension.29,30 Sleep alters autonomic nervous system function and other physiologic events that influence Blood Pressure. Sleep disorders like insomnia and 
obstructive sleep apnoea could affect body's ability to regulate stress hormones leading to high blood pressure.

\section{CONCLUSION}

In the present study, the prevalence of prehypertension is more among the students as compared to prevalence of hypertension and more so in males as compared to females. The early intervention can help in reducing the progression to hypertension. One important way of preventing prehypertension and hypertension would be to educate and bring awareness among the masses and stress on the importance of lifestyle modification and maintaining a healthy lifestyle right from the beginning and thus helping in reduction of overall prevalence of non-communicable disease in the community.

\section{REFERENCES}

[1] World Health Organization (WHO). World health statistics 2016: monitoring health for the SDGs, sustainable development goals. Geneva, 2016.

[2] Vimala A, Ranji SA, Jyosna MT, et al. The prevalence, risk factors and awareness of hypertension in an urban population of Kerala (South India). Saudi J Kidney Dis Transpl 2009;20(4):685-9.

[3] Gupta R. Trends in hypertension epidemiology in India. J Hum Hypertens 2004;18(2):73-8. https://doi. org/10.1038/sj.jhh.1001633

[4] Khan MI, Lala MK, Patil R, et al. A study of the risk factors and the prevalence of hypertension in the adolescent school boys of Ahmedabad city. Journal of Clinical and Diagnostic Research 2010;4(6):3348-54.

[5] Avadhesh K, Manushi S, Shamshad A et al. Prevalence of hypertension and awareness of its predictors among fresh undergraduate medical students of Banaras Hindu University. Standard Global Journal of Medicine and Medical Sciences 2014;1(3):46-50.

[6] Chobanian AV, Bakris GL, Black HR, et al. The seventh report of the Joint National Committee on prevention, detection, evaluation and treatment of high blood pressure: the JNC 7 report. JAMA 2003;289(19):256072.

[7] Vasan RS, Larson MG, Leip EP, et al. Assessment of frequency of progression to hypertension in nonhypertensive participants in the Framingham Heart Study: a cohort study. Lancet 2001;358(9294):1682-6.

[8] WHO. Obesity: preventing and managing the global epidemic. Report of a WHO Consultation on Obesity, World Health Organisation, Geneva, Switzerland, 1998.

[9] Asmathulla S, Rajagovindan D, Sathyapriya V, et al. Prevalence of prehypertension and its relationship to cardiovascular disease risk factors in Puducherry. Indian J Physiol Pharmacol 2011;55(4):343-50.

[10] Mahmood SE, Ansari SH. Prevalence of prehypertension and hypertension in rural Bareilly. Natl J Med Res 2012;2(3):291-4.

[11] Setty SS, Naik A. Prevalence of prehypertension amongst medical students in coastal Karnataka. J Evol Med Dent Sci 2012;1:975-80.
[12] Pradeepa R, Mohan V. Hypertension \& prehypertension in developing countries. Indian J Med Res 2008;128(6):688-90.

[13] Kulkarni MM, Hemagiri K, Malavika, et al. Prehypertension and associated factors among medical students of SSIMS and RC, Davangere -- a cross-sectional study. J Indian Med Assoc 2011;109(10):733-4, 736.

[14] Brar S, Badaruddoza A. Epidemiology of blood pressure in relation to certain quantitative traits among urban Punjabi adolescents. Asian J Pharm Clin Res 2013;6(2):319-25.

[15] Chitrapu RV, Thakkallapalli ZM. Prehypertension among medical students and its association with cardiovascular risk factors. J NTR Univ Health Sci 2015;4(1):8-12.

[16] Thangjam RS, Singh AI, Rothangpui, et al. The profile of Blood Pressure (BP) and the prevalence of hypertension in school going children aged 5-15 years of Manipur, a North-Eastern hilly Indian state. Int J Contemp Pediatr 2017;4(6):2151-7.

[17] Kumar SK, Singh AB, Asem P. Prevalence, awareness, treatment and control of hypertension in urban communities of Imphal, Manipur. International Journal of Interdisciplinary and Multidisciplinary Studies (IJIMS) 2015;2(3):61-70.

[18] Bhattacharjya H, Debbarman DK, Tripura A, et al. Prevalence, determinants and awareness regarding hypertension among adults in a rural area of Manipur. Journal of Evolution of Medical and Dental Sciences 2013;2(52):10133-43.

[19] Shah A, Afzal M. Prevalence of diabetes and hypertension and association with various risks factors among different Muslim population of Manipur, India. Journal of Diabetes \& Metabolic Disorders 2013;12:52.

[20] Srivastava AK, Kandpal SD, Negi KS, et al. Prevalence and risk factors of hypertension among medical college students, HIMS, Dehradun. Indian J Prev Soc Med 2012;43(1):43-6.

[21] Chhabra P, Grover VL, Aggarwal K, et al. Nutritional status and blood pressure of medical students in Delhi. Indian Journal of Community Medicine 2006;31(4):248-51.

[22] Tripathy JP, Thakur JS, Jeet G, et al. Alarmingly high prevalence of hypertension and pre-hypertension in North India-results from a large cross-sectional STEPS survey. PLoS One 2017;12(12):e0188619. https://doi.org/10.1371/journal.pone.0188619.

[23] Manimunda SP, Sugunan AP, Benegal V, et al. Association of hypertension with risk factors \& hypertension related behaviour among the aboriginal Nicobarese tribe living in Car Nicobar Island, India. Indian J Med Res 2011;133(3):287-93.

[24] Sharma A, Grover N, Kaushik S, et al. Prevalence of hypertension among schoolchildren in Shimla. Indian Paediatrics 2010;47:873-6.

[25] Nyombi KV, Kizito S, Mukunya D, et al. High prevalence of hypertension and cardiovascular disease risk factors among medical students at Makerere University College of Health Sciences, Kampala, Uganda. BMC Res Notes 2016;9:110. 
[26] Mazor-Aronovitch K, Lotan D, et al. Blood pressure in obese and overweight children and adolescents. Isr Med Assoc J 2014;16(3):157-61.

[27] Giri S, Sharma SR, Timalsina S, et al. Cardiovascular health risk behaviour among medical students in a teaching hospital. J Nepal Health Res Counc 2012;10(22):187-91.

[28] Bertsias G, Mammas I, Linardakis M, et al. Overweight and obesity in relation to cardiovascular disease risk factors among medical students in Crete, Greece. BMC Public Health 2003;3(3).
[29] Goel M, Pal P, Agarwa A, et al. Relationship of body mass index and other lifestyle factors with hypertension in adolescents. Ann Pediatr Cardiol 2016;9(1):29-34.

[30] Leung LC, Ng DK, Lau MW, et al. Twenty four hour ambulatory BP in snoring children with obstructive sleep apnea syndrome. Chest 2006;130(4):1009-17. 